\title{
Coping with COVID and the Myth of a Collective China
}

\author{
Bart DESSEIN*
}

\begin{abstract}
Reflecting on the development of the global economic system, the present article describes the phenomenon of hyper-individualism in the age of "second modernity" and, making a distinction between the "family collective" and the "patriotic collective", discusses the individual's oscillating loyalty between the family and the nation state in this process. An answer is sought to the question why, in the contemporary period, individuals who are confronted with a (health) crisis appear to have lost confidence in the authority of the nation state, regardless of whether they live in a country with a democratic government or one with an authoritarian regime. Building on this finding, the article also addresses the importance of a revival of the political agora.
\end{abstract}

Keywords: neoliberalism, second modernity, social action, globalization, locality

\section{Soočanje s COVID-19 in mit o kolektivni Kitajski \\ Izvleček}

Kot razmislek o razvoju globalnega ekonomskega sistema pričujoči članek opisuje pojav hiperindividualizma v obdobju »druge modernosti«. Avtor razlikuje med »družinskim« in "patriotskim kolektivom « ter na tej osnovi prikaže, kako v tem procesu posamezniki in posameznice nihajo med družino in nacionalno državo. Članek išče odgovor na vprašanje, zakaj vse kaže na to, da posameznice in posamezniki, ki se soočajo z (zdravstveno) krizo, v sodobnem času izgubljajo zaupanje v nacionalno državo, in sicer ne glede na to, ali živijo v državi z demokratično vlado ali v takšni, ki ji vlada avtokratski režim. Na osnovi rezultatov pričujoče študije avtor izpostavi tudi pomen preporoda politične agore.

Ključne besede: neoliberalizem, druga modernost, družbena aktivnost, globalizacija, lokalnost

\section{Introduction}

Soon after the SARS-CoV-2 (hereafter COVID-19) virus hit Europe and the different European governments—so it appeared—struggled with their efforts to

Bart DESSEIN, Ghent University.

Email address: Bart.Dessein@ugent.be

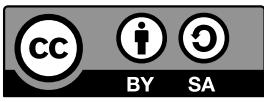


halt the spread of the virus, mainstream Western media were full of praise about the effectiveness with which China had managed to control the spread of the virus (in the appendix to this article, two sets of figures of total numbers of infections and death toll, as released by the Johns Hopkins University, Baltimore, Maryland, USA, are given. The first set are the data released on 9 December 2020 at 09:26; the second are the data released on 1 March 2021 at 13:24). There were many "analyses" that explained how democracies had proven to fall behind in efficiency in countering the pandemic as compared to authoritarian regimes, and, in line with the above, noting that Western individualist societies were less efficient than Asian collective societies. This bold statement brings the questions to the fore as to whether Chinese society can indeed by characterized as "collective" and whether the apparent obedience of the Chinese population to the rules that were imposed by the Chinese government is indeed a proof of the perceived effectiveness of authoritarian traits of the Chinese political system. To develop an answer to these questions, the present article makes a fundamental distinction between the "family collective" and the "patriotic collective", and addresses the consequences the development of the "second modernity" of neoliberalism-in no way synonymous with liberal democracy - has had for the relations among the individual, family, and nation state. This will enable us to at least nuance the cultural absolutism that is at the basis of the "collective Asia" vs. "hyper-individualistic West" dichotomy and that informs the argumentation in Western media reports on the success vs. failure of coping with the COVID-19 crisis. On this basis, the article also addresses the importance of a revival of the political agora to avoid our liberal democracies developing into illiberal authoritarianism.

\section{Some First Considerations}

In the different assessments of the way China dealt with the COVID-19 crisis as compared to Western countries a few arguments to explain China's effectiveness kept emerging in mainstream Western media. Probably most prominent were the claims that authoritarian countries would be better able than democracies to cope with crises of the magnitude of COVID-19; that China would have been more alert than Western countries were; that (European) corruption would be detrimental to effective handling of the pandemic, while efficient government administrations would be conducive to more effective actions; or that the blame was to be put on the individualism that is characteristic of Western societies, different to collective Asian societies. It is not difficult to give counter-arguments that at least cast serious doubt on the soundness of most of these statements. If authoritarianism would be the better political system to cope with health crises, how 
then are we to explain the relatively better figures for Taiwan or the Republic of Korea in the period under scrutiny? Might it not be that praising authoritarianism suited an altogether very different domestic political agenda in some Western countries? ${ }^{1}$ It may be true that, generally speaking, Northern European countries are perceived to be the least corrupt within the European Union (with Denmark, Finland and Sweden in the top 3 positions with scores of 87, 86, and 85 on a scale of 100 in the 2019 Corruption Perception Index) (European Commission 2020), but does this also apply to China? And how can we explain that Denmark, which was seen as least corrupt, was ranked 68th in terms of the number of infections and deaths on 9 December 2020 (climbing to number 58 on 1 March 2021), while Sweden with an almost negligible difference in the 2019 Corruption Perception Index (85 to 100) was 36th in the number of infections and deaths on 9 December 2020 (climbing to 29 on 1 March 2021)? Moreover, are corruption and an inefficient government administration not correlated? And is, therefore, the claim that efficient government administrations are conducive to an effective dealing with the crisis not tantamount to claiming that authoritarian systems are better suited to deal with a health crisis?

That the alertness of governments is conducive to efficiently dealing with a health crisis goes without saying. It is in this respect important to note that when the COVID-19 crisis broke out it is very likely that the governments and populations of East Asian countries were still well aware of the SARS (Severe Acute Respiratory Syndrome) disease that broke out in China in 2003 and spread to four other countries. ${ }^{2}$ This awareness may indeed have prompted the governments and populations in these countries to a swift reaction, regardless of whether or not the country concerned has an authoritarian or a democratic political system. This observation is confirmed in The Lancet Infectious Diseases of 1 November 2020. In this issue, Gregory Poland, Director of the Vaccine Research Group of Mayo Clinic, Rochester, Minnesota, USA, is quoted as follows: "In China, you have [...] a population that takes respiratory infections seriously" (Burki 2020).

He adds to this that the Chinese success is also the result of a population that is:

willing to adopt non-pharmaceutical interventions, with a government that can put bigger constraints on individual freedoms than would be considered acceptable in most Western countries [...]. (ibid.)

1 According to The Economist Intelligence Unit 2020, Taiwan ranked 11 of the 167 countries listed as strongest democracies. This is up from rank 31 in 2019. The 2020 top five democratic countries in the world are, according to this list, Norway, Iceland, Sweden, New Zealand and Canada (The Economist Intelligence Unit 2020).

2 See "Severe Acute Respiratory Syndrome (SARS)" (WHO n.d.). 
In the same article, Han Fu of Imperial College in London seconded the importance of compliance with government rules. He stated: "Other factors such as [...] civil compliance with regulations may also affect the effectiveness of the response." (ibid.)

Compliance with rules was also characterized by Gregory Poland as a typical attitude that makes Asia different from the West. He stated:

Commitment to the greater good is engrained in the culture; there is not the hyper-individualism that characterizes parts of the USA, and has driven most of the resistance to the countermeasures against the coronavirus. (ibid.)

The claim here is that Asian societies are characterized as collective and take care of the greater good, whereas the USA (and, more generally, the West) are hyper-individualistic. In what follows, this contention will be scrutinized, and some reflections will be formulated on the relation between hyper-individualism and resistance to government countermeasures.

\section{Culturalism, Modernity, and Second Modernity}

When, in $206 \mathrm{BCE}$, political power in China returned to the hands of the feudal lords who had been removed from their positions when Qin Shi Huangdi united the different feudal territories and founded the Qin dynasty in $221 \mathrm{BCE}$, these feudal lords reinstated the social structures that had existed prior to China's unification, and Confucianism was crafted into these inherited structures as the official doctrine. A Confucian bureaucracy with functionaries who were selected on the basis of their knowledge of the Confucian principles was then installed to administer the Chinese "body politic" of the Han dynasty (206 BCE-220 CE). In practice, this meant that a fundamental distinction between, on the one hand, the Confucian elite, and, on the other hand, the popular culture of agricultural communities, was installed.

In the eyes of the Confucian elite- a social group that did not possess any specific professional knowledge but the members of which were the representatives, executors, and protectors of Confucian culture-it was their elevated morality that made it possible that the peasants paid their taxes without the use of coercion, and it was regarded as morally correct for the peasants not to interfere with the elite culture and to only engage themselves with their appropriate agricultural communities. Each of these primary agricultural communities had its own peculiar 
characteristics, but all of them had two traits in common: 1) their type of economy: intensive farming, and 2) their subordination to the elite culture (see Stover 1974, 101-7).

The economic reality for the individual peasant-roughly 90 per cent of the Chinese population - was that the soil he tilled was his only means of subsistence and that it was his paying of taxes that gave him the right to till the soil. In circumstances of unremitting economic hardship, interfering in another family or village community could only lead to reprisal and punishment. The family was therefore the peasant's only insurance against the interests of other families and against the state at large. The fact that the peasant depended on his immediate family and kinship group for shelter and security against the vicissitudes of life forced every family to only focus on their own economic interests (see on this Cohen 1976, 11). The outcome of this was that each family accumulated wealth for itself, to the detriment of other families, and each individual contribution to family wealth was part of that family's achievement. ${ }^{3}$

The social networks that functioned in Chinese society were the obvious outcome of this political and economic "culturalist" model. Chad Hansen (1985) has described Chinese society as characterized by a "part-whole structure". The smallest "part" in this "part-whole structure" is an individual, and the "whole" is a larger structure of which each individual is a part. It is important to note that in a "part-whole structure" not only can each part, in its turn, be part of something still bigger - an individual, for example, is part of her/his core family, which in its turn is part of a local agricultural community, etc.- but that each part can also simultaneously be part of different larger wholes-a woman is thus not only part of her own core family, but is, upon marriage also, be it in a different way, part of her husband's family. Each "part-whole relationship" hereby represents a specific social relation-a guanxi, and with each of these relations, a peculiar code of (ritual) conduct is connected. Anne Cheng $(1997,37)$ put this as follows:

The result is a vision of the world, not as a set of discrete and independent entities, each of which constitutes in itself an essence, but as a continuous network of relations between the whole and the parts, without one transcending the other. (Author's translation of the original French)

One of the consequences of this "living in a web" is that the web is part of the individual. The "self" is imbedded in relations and does not exist independently from these relations (Redding 1995, 62). The famous Chinese social scientist

3 See Wilson and Pusey $(1982,199)$. For a more elaborate treatment of China as a peasant society see Wolf (1966). 
Fei Xiaotong called this type of social model a "differential model of association" (chaxu geju 差序格局). He illustrated this type of relationship with the metaphor of concentric circles that appear when throwing a pebble into the water (Fei 1992, 62-63). The circles of one individual cross the circles of other individuals at different moments, and each interference of one's own circles with those of another individual stands for a separate form of relation and a separate and peculiar code of (ritual) conduct that is connected to it. That the moral code of conduct is connected to specific guanxi-relations means that the Chinese model of social organization is particularistic; it has no universal ethical concepts that go beyond specific and peculiar types of interhuman relations (See Fei 1992, 74). As alluded to above, in social and economic terms each guanxi-relation boiled down to increasing and protecting family wealth (Redding 1995, 67). To reach this goal, an individual had to make use of the network of social relations that were at her/his disposal, and had to preserve these relations loyally. In these circumstances, the Chinese type of "trust" was founded on personal reputation, it was not the type of "trust" codified in laws. The absence of a "civil society" that characterized China's dual society hereby deprived the peasant of a "space" to negotiate his economic, social and political position. That is to say, the political status of the peasant was one of "non-participation" in politics, and social mobility was in practice virtually impossible.

Here the role of Confucian rituals comes in. Aware of the scarcity of material goods, Xunzi (ca. 310-ca. 235 BCE), a disciple of Confucius (trad. 551-479 BCE) whose ideas would become important in the formation of Confucian state ideology, advocated the instalment of strict social divisions. As Xunzi 5.4 states:

What is it that makes a man human? I say that it lies in his ability to draw boundaries [...] Of such boundaries, none is more important than that between social classes. Of the instruments for distinguishing social classes, none is more important than ritual principles. (Translation: Knoblock 1990, Vol. I, 206)

人之所以為人者何已也, 曰以其有辨也 [...] 辨莫大於分, 分莫大 於禮。

In the Confucian state, rituals therefore had a double function: they served as a guideline for individual conduct and, by keeping human behaviour within "ritual boundaries", they also offered the possibility to adjust this individual behaviour so as to "harmonize" society at large (see El Amine 2015, 92). ${ }^{4}$ A "harmonious socie-

$4 \quad$ El Amine $(2015,33)$ therefore suggests seeing "the dispositions sought for the common people (to refrain from stealing, to work hard, and to be 'correct') as dispositions relating to orderliness, rather than virtuousness". 
ty", to quote Loubna El Amine $(2015,14)$ is "achieved through the maintenance of a system of rituals ( $(i)$ that all members of society abide by". To this can be added that ancestor worship, a practice that is by definition restricted to the core family, brought the social relations that exist between the living to a transcendent level. This further cemented the existing division between the elite and popular cultures.

This social and political particularity of traditional China that was maintained throughout the Chinese empire very much resembles the situation Karl Marx describes for 19th century France in The Eighteenth Brumaire of Louis Bonaparte, published in the journal Die Revolution in 1852:

The small peasants form a vast mass, the members of which live in similar conditions, but without entering into manifold relations with one another. Their mode of production isolates them from one another, instead of bringing them into mutual intercourse. The isolation is increased by France's bad means of communication and by the poverty of the peasants. Their field of production, the small holding, admits of no division of labor in its cultivation, no application of science and, therefore, no multiplicity of development, no diversity of talents, no wealth of social relationships. Each individual peasant family is almost self-sufficient; it itself directly produces the major part of its consumption and thus acquires its means of life more through exchange with nature than in intercourse with society. The small holding, the peasant and his family; alongside them another small holding, another peasant and another family. A few score of these make up a village, and a few score of villages make up a Department. In this way, the great mass of the French nation is formed by simple addition of homologous magnitudes, much as potatoes in a sack form a sackful of potatoes. In so far as millions of families live under economic conditions of existence that divide their mode of life, their interests and their culture from those of the other classes, and put them in hostile contrast to the latter, they form a class. In so far as there is merely a local interconnection among these small peasants, and the identity of their interests begets no unity, no national union and no political organization, they do not form a class. They are consequently incapable of enforcing their class interest in their own name, whether through a parliament or through a convention. (Tucker 1978, 608)

$5 \quad$ Marx wrote The Eighteenth Brumaire of Louis Napoleon between December 1851 and March 1852. The "Eighteenth Brumaire" refers to November 9, 1799 in the French Revolutionary Calendar, the day that Napoleon Bonaparte had put an end to the French Revolution, and ushered in the Napoleonic era by seizing power in a coup d'état. 
In Hong gaoliang jiazu 红高粱家族, a novel set in 1930s China, Mo Yan 莫言 gives a succinct description of how the importance of the family in Chinese society continued into the early Republic. In the translation by Howard Goldblatt $(1993,85)$, the passage that describes the threat to the "family collective" that comes along with the fact that women are married into the family of their husbands and, as such, necessarily form bonds with other families, reads as follows:

What turns the sorghum of Northeast Gaomi Township into a sweet, aromatic wine that leaves the taste of honey in your mouth and produces no hangover? Mother told me once, making sure I understood that I was not to give away this family secret, for, if I did, not only would our family's reputation suffer, but if our descendants ever decided to set up another distillery they'd have lost their unique advantage. Without exception, the craftsmen from our neck of the woods live by a simple rule: they would rather pass on their skills to their son's wives than to their daughters. This established practice carries the same weight as the law in certain countries.

高密东北乡红高粱怎样变成了香气馥郁、饮后有蜂蜜一样的甘饴 回味、醉后不损伤大脑细胞的高粱酒? 母亲曾经告诉过我。母亲 反复叮咛我: 家传秘诀, 决不能轻易泄露, 传出去第一是有损我 家的声誉，第二万一有朝一日后代子孙重开烧酒公司，失去独家 经营的优势。我们那地方的手艺人家, 但凡有点绝活, 向来是宁 传媳妇也不传闺女，这规矩严肃得像某些国家法律一样。6

In the West, the Industrial Revolution and age of (first) modernity transformed local economies that had been based on agriculture and handicrafts, and that were organized in the context of core families, into economies based on mechanized manufacturing. New technologies and new ways of organizing work made the existing industries more productive and efficient, and enlarged the scale of industrial production from localities to the nation state. This first happened in England around 1750 and in the rest of Europe in the early nineteenth century. Along with the changes in the volume and the organization of factory work, the gradual development of a juridical system, the neutrality and universal principles of which were guaranteed by a neutral state, also opened the road for the individualization of European societies (see Redding 1995, 136-37). The power of national political institutions and the establishment of the socially integrating institutions that are typical for the age of first modernity, such as organized religion and workers'

6 莫言, «红高粱家族》 http://www.dushu369.com/zhongguomingzhu/HTML/77684.html. (Accessed March 13, 2021) 
unions that guaranteed workers the necessary safety, enabled the workers to shift (part of) their loyalty from the family business to the higher goal of the nation state. The territorial expansion of economic activity, and the insurance of individual legal protection that characterizes this epoch, enhanced the individual's freedom of movement and radius of action.

Different from previous economic globalization processes that were the result of an increase of labour in individual localities or, for the nineteenth century, in nation states, the globalization of the era of neoliberalism that began in the 1980s is one that rejects labour in favour of capital accumulation, because investing in labour and production yields less results than investing in capital. Neoliberalism is therefore characterized by an enormous increase in capital without a parallel increase in the real economy (Verhaeghe 2020,36). According to French economist and sociologist Jean-Paul Fitoussi (1997), a structural problem therefore ensues: in absolute figures, the global quantity of available work is shrinking (Fitoussi 1997, referred to in Bauman 2006, 19). This means that the neoliberal focus on capital accumulation arguably also constrains the freedom of movement of a growing number of "underclass" citizens, i.e., the growing number of people who, because their skills have become redundant and/or because they have failed to catch up with the speed of the ever-changing second modernity of neoliberalism, have been squeezed out of the production process and become deprived of the concomitant means for individual development that labour had "traditionally" brought about (Baumann 2020, 101). Moreover, with "capital and commodity markets", as Zygmunt Bauman $(2020,148)$ claims, having now "moved into a new societally extraterritorial space, situated well above the realm of nation states' sovereignty and so beyond the reach of their supervising/balancing/mitigating capacity" (emphasis in original), the control over crucial economic factors has shifted from the institutions of (national) government to the free play of market forces (see Castells 2010, 356). In the era of neoliberal globalization, nation states have therefore not only become "economically senseless", but also their political institutions have increasingly become "remnants of the past" (Bauman 2020,148). With real power increasingly removed from politics and the political agora - the "gathering place" to negotiate social and political order-and with capital chasing the least regulations, the neoliberal "society" is not only characterized by a sharp deterioration in life security for a growing number of citizens (see Castells 2009, 177), but also by decreasing possibilities for these citizens to maintain the political consultation with their local and national governments over the conditions in which they offer their labour. As economic power is shifting to extraterritoriality and as the power of those national institutions that had traditionally maintained the security of national citizens is 
reduced, a "waning of expectations that salvation may come from government buildings, whoever their current or future occupants may be" (Bauman 2006, 19), has emerged.

China's economic development that started with the reform and opening up policies (gaige kaifang 改革開放) at the end of the 1970s has also gradually brought this country into the neoliberal system. It is important to take into account, however, that when China entered into the neoliberal system it was not yet a fully developed industrial nation state. To the extent that in China not all local economic power had already been shifted to the nation state- the famous periods of the Great Leap Forward (1958-1961) and of the Great Proletarian Cultural Revolution (1968-1976) even saw a new emphasis on the importance of localities - and that the development of civil law based on universal ethical concepts that go beyond specific and peculiar types of interhuman relations was only in its infancy, the country had remained—and still remains—a highly "localized" nation state. ${ }^{7}$ This may help to explain why, as Daniel A. Bell $(2006,15)$ claimed, while modern East Asian countries may have incorporated individual concepts such as property rights, they still tend to, both in terms of justice and morality, see possession as the possession of the whole family, including that of the aging parents. ${ }^{8}$

\section{Hyper-Individuality and Family Resilience}

Both in Western liberal democracies in which individual agency came to be regulated through juridical codes that are guarded by a neutral state and that protected the individual in her/his actions, ${ }^{9}$ and in the traditional Chinese context where

7 During the Great Leap Forward (da yuejin 大跃进), rural China was reorganized in communities that resembled traditional kinship groups that, with the disastrous outcome of this economic experience, "paradoxically" strengthened the old community loyalties (see Perry 2001, 288-94). The actions of the Red Guards (hong weibing) during the Great Proletarian Cultural Revolution reduced individual trust to, at most, a very restricted kinship group.

8 Commenting on the overseas Chinese, Redding $(1995,3)$ remarks that they have developed one particular form of organization - the family business - and kept to it. The family business remains in essence a family fortress, and at the same time an instrument for the accumulation of wealth by a very specific set of people. Schmidt-Glintzer $(2009,11)$ noted that with the instalment of the People's Republic of China, the Chinese citizen has given up individual freedom in favour of the unity and independence of the nation state under CCP rule.

9 Bauman $(2006,155)$ states that "Liberal democracy $[\ldots]$ aspires to square one of the most notorious of the notoriously unsquarable circles - to preserve the liberty to act of, simultaneously, state, individuals and their associations, while making the liberty of each a condition of the freedom of the others." 
the individual acted within the confines of guanxi-relations that were built on mutual trust, these respective forms of assured solidarity have been a prerequisite for individuals to "act in freedom", because the absence of trust and security makes free enterprise a precarious undertaking. ${ }^{10}$

At this point, we need to address the interchangeability of the family and the nation state. Both the family and nation are means to overcome the futility of personal existence in the sense that they place individual existence in a historical lineage and give sense to individual life through labour in favour of those coming after us, be it in the family or in the nation. ${ }^{11}$ The degree to which the nation state can effectively become an alternative for the family depends, I contend, on the degree to which juridically protected individuality has been established. Conversely, when the nation state appears to be no longer capable of (juridically) protecting the individual, individuals will be inclined to divert their loyalty away from the nation state. That is to say, for a growing number of individuals who are pushed out of the neoliberal system - those citizens whom Zygmunt Bauman $(2006,170)$ called the "locals-by-default" in contradistinction to the "globals-by-choice", i.e., the ideologues and executers of contemporary globalization- the shrinking ability of the political institutions of the nation state to take care of them through an organized system of social security, may result in them feeling the need for alternative protective structures. This may be but does not have to be, as I discuss hereafter, the family.

The entry of neoliberalism may have shifted the powers that determine the fate of an individual's life to extraterritoriality, but this does not mean that the individual lives of the majority of the people do not remain predominantly local. Therefore, the security of the sound functioning of civil society and the political agora may have made it possible for each individual "citizen" in Western societies to increasingly dissociate her/himself from the constraints of the family and to go on the path of "hyper-individuality", it is arguably this same "hyper-individuality" that has left the same Western individual defenceless in a neoliberal society in which the power of national institutions has been crippled. This is where the totalitarianism of neoliberalism and the privatization of security come in. As Hannah Arendt $(1958,474)$ put it:

10 Bauman $(2020,21)$ notes that "in the society of individuals, we all and each one of us are individuals-de jure. That is, individuals by law: written law, but also its unwritten variety, no less powerful for being unwritten - by the diffuse yet continuous, overpowering and irresistible pressure of 'social fact'."

11 Both the nation and the family have the possibility, to speak with Zygmunt Bauman (2006, 38), to make one's own "individual mortality a tool of collective immortality". 
[I]solation is, as it were, pretotalitarian; its hallmark is impotence insofar as power always comes from men acting together; [...] isolated men are powerless by definition. ${ }^{12}$

The fact that, in the West, neoliberalism was introduced in a socio-economic context of already matured hyper-individuality may help to explain why a crisis of the political institutions may conduce the Western individual not to return to the "family collective", but to an "ersatz family of her/his own individual choice", much more so than this is the case for her/his Chinese homologue. ${ }^{13}$ This drive is described as follows by Adorno $(1998,276)$ :

[A]s recompense for his jumping into the "melting pot" (in which all ingredients lose their individuality) he (= the individual) is promised the grace of being chosen, of belonging. Weak and fearful people feel strong when they hold hands when running.

As noted above, in China, by contrast, the balance between family and nation state had not yet fully shifted "in favour" of the nation state at the moment the country entered the neoliberal economic system. This is partly related to the fact that in traditional Chinese society an individual did not exist without his guanxi-relations, and social organization and law were particularistic. As a result, the motivation for hyper-individualism to develop was largely absent. Related to this is the fact that it was only from the middle of the nineteenth century onwards that the unwanted presence of the West first gave rise to nationalist feelings in all layers of Chinese society-in contrast to the "cultural model" in which the elite shared a "proto-national" identity but the general population did not participate. ${ }^{14}$ As is well known, the privatization of the Chinese economy in the early 1980s in practice meant that it was local cooperatives in particular that became the new owners of the erstwhile state economy. This, coupled with the fact that, in China, a civil society had not developed and legally guaranteed individual freedoms did not exist in the same way as they do in Western countries (see Peerenboom 2007, 31-32), - an important exception has to be made here for the ideologues and

12 Bourdieu (1997) stated that "precariousness renders the whole future uncertain, and so forbids all rational anticipation and in particular disallows that minimum of hope in the future which one needs to rebel". (Author's translation of the original French). Also see the quotation of Karl Marx given above.

13 Biscop (2020) noted: "Many people no longer feel that they have a personal responsibility to assume. This is probably why Japan, South Korea, and Taiwan perform so much better in controlling the outbreak than we."

14 For the development of Chinese political nationalism in all layers of Chinese society see Harrison (2001, 165-66, 216-17). 
executors of the neoliberal order themselves ${ }^{15}$ - may help to explain why, in the circumstances of the pandemic, for the Chinese "locals-by-default" of the neoliberal era, a return to the "family collective" for protecting one's own health and the health of one's family is a more viable alternative for the "patriotic collective" than may be the case for a Western individual who clings to her/his acquired individual freedom. I therefore contend that the seemingly Chinese following of rules imposed by the state in the Covid-19 pandemic may have more to do with family maintenance than with loyalty to the government. ${ }^{16}$

\section{Second Modernity and the Issue of Health Care}

The shifting of responsibility for insurance against uncertainty to the individual and the associated privatization of insurance that comes along with the neoliberal organization of "society" applies to both China and the West. In China and in Western countries alike, the nation state has left health care to "big business" that has been "making money" with buying and monopolizing the patents of existing medicines, more than it has been investing in the development of new medicines and vaccines (Mak 2019, 46-48). In an article in International Journal of Health Policy and Management, Mostafa Shookoohi, Mehdi Osooli and Saverio Stranges $(2020,1)$ note that:

while the health systems of most western countries have prioritized hospital-centered management of non-communicable diseases, their capacity to prevent and control emerging infectious diseases has not been given adequate attention, with relatively limited public investments to strengthen epidemiological surveillance systems in the community.

Also in China, the introduction of market reforms in the late 1970s has led to a collapse of the health system. While at the beginning of the reform and opening up policies in 1978, a Chinese citizen only had to pay 20 per cent of the medical

15 Since 2016, China has had more billionaires than the United States with, in 2020, 1,058 (as compared to 696 for the United States). See Ding (2021), who states that "China has the world's most billionaires-more than the United States, India and Germany combined-due to a flurry of new initial public offerings and the booming digital economy over the past year despite the pandemic, according to the latest Hurun rankings."

16 The latter may also relate to the preference for the care of elderly parents in China: 45 per cent of Chinese want their parents to live with them, 47 per cent prefer to let them live independently, and only 2 per cent want their parents to live in a nursing home (6 per cent preferred another, undefined, option). These figures may also be explained through the importance of the traditional "family collective". (See Wang, Morris and Brubaker 2016) 
costs from their own savings, this had risen to 60 per cent by 2008 , and had left the majority of the rural population without medical insurance (Yip and Hsia 2008). In an interview with AsiaNews on 10 April 2005, Yu Zonghe, then deputy chairman of the Chinese Hospital Association lamented that "By asking hospitals to make profits to finance expenses, the government is shirking its responsibility". In the same report, Zhu Qingsheng, then Vice Minister of Health is quoted saying that in 2004 his Ministry received only 1.6 per cent of the government's annual budget, of which most went to the cities. As a result "only 30 per cent of the medical expenditure is spent on farmers, who comprise 70 per cent of the population. The urban population, which makes up 30 per cent, enjoys 70 per cent of the medical resources" (AsiaNews 2005). Further, according to Zhu Qingsheng about 45 per cent of urban residents and 79 per cent of people living in rural areas were not covered by any insurance plan in 2004, and anywhere between 40 to 60 per cent of farmers could not afford medical care (ibid.). ${ }^{17}$ Despite the statement in the new "Law of the People's Republic of China on the Promotion of Basic Medical and Health Care", issued by the Standing Committee of the National People's Congress (2019a) on 28 December 2019 (in effect as from 6 January 2021) that the people's governments at or above the county level "shall provide basic public health services", that the state "shall provide vaccines in the immunization program for residents free of charge ... provide basic medical services according to residents' health conditions and medical needs" and "establish and improve the medical service system $[. .$.$] that completely covers urban and rural areas, [...] and$ improve the rural medical service networks and urban community health service networks", ${ }^{18}$ and despite the 'Vaccine Administration Law of the People's Re-

17 Kaufman $(2010,288)$ notes that "By the end of the 1990s, medical expenses topped the list of reasons that rural families gave for falling into poverty". The "China Health Care Forum Summary Report (2005-2015)" states that, in the year 2013, "by increasing government spending, China has rapidly extended basic medical insurance coverage to the vast majority of its urban and rural residents and strengthened its medical infrastructure at the grassroots level over the past four years. However, it is impossible to solve the long-standing and deep-rooted problems in the healthcare sector by simply increasing government spending. Other measures which can deepen healthcare reform and encourage institutional and organizational innovations should also be implemented".

18 Article 15: “基本公共卫生服务由国家免费提供”; Article 18: “县级以上人民政府通过举办专 业公共卫生机构、基层医疗卫生机构和医院, 或者从其他医疗卫生机构购买服务的方式提 供基本公共卫生服务”; Article 21: “国家实行预防接种制度, 加强免疫规划工作。居民有依 法接种免疫规划疫苗的权利和义务。政府向居民免费提供免疫规划疫苗”; Article 31: “国家 推进基层医疗卫生机构实行家庭医生签约服务, 建立家庭医生服务团队，与居民签订协 议, 根据居民健康状况和医疗需求提供基本医疗卫生服务”; and Article 34: “国家建立健全 由基层医疗卫生机构、医院、专业公共卫生机构等组成的城乡全覆盖、功能互补、连续协 同的医疗卫生服务体系。国家加强县级医院、乡镇卫生院、村卫生室、社区卫生服务中心 （站）和专业公共卫生机构等的建设, 建立健全农村医疗卫生服务网络和城市社区卫生服 务网络”。 
public of China' of 29 June 2019 (Standing Committee of the National People's Congress 2019b) (in effect as of 1 December 2019) that stipulates that "the price of the vaccine is set independently and reasonably by the holder of the vaccine marketing license in accordance with the law; the price level, price difference, and profit margin of vaccines should be maintained at a reasonable range", ${ }^{19}$ the effects of commercialization of health care and the impact this has on the "locals-by-default" vs. the "globals-by-choice" in contemporary China are illustrated by Flynn Murphy (2020, 51), who writes:

Investigations reveal that experimental vaccines are available to anyone willing to pay for them in some parts of China. In the city of Yiwu, for example, Britain's national broadcaster the $\mathrm{BBC}$ interviewed people queuing to pay around US\$60 to receive a dose.

While capital may inhabit cyberspace, it is the physical space that remains of primordial importance for individual life, and it is those political institutions that protect this individual life that are valued. In times of a health crisis, these, so it seems, are increasingly local institutions. An interesting graph in this respect was published in The Economist of 20 October 2020. It shows that the outbreak of SARS in 2003 in China led to a decrease in public satisfaction with the central government, but to an increase in satisfaction with the provincial government, an even larger increase in satisfaction with the government on a county level, and a sharp increase in satisfaction with the township government. ${ }^{20}$ This corroborates the earlier statement that Chinese citizens turn away from the patriotic collective in times of a (health) crisis.

\section{Individual Religion and the Loss of'Trust in Science}

An important side-effect of the reduction of an individual's ability to exercise her/his rights as a citizen is that trust in one's identity as "citizen" itself is also reduced. A citizen who, in a neoliberal society, is deprived of her/his identity as "citizen" is reduced to a consumer who less and less feels the sense and need to participate in democratic dialogue and the running of the state, or to comply with government-imposed rules (Bauman 2006, 156). In such circumstances alternative identities are sought, and individual religions are created. Analysing current developments in the world of second modernity, Simon Speck $(2013,27)$ noted that a complex of economic, social

19 Article 33: “疫苗的价格由疫苗上市许可持有人依法自主合理制定。疫苗的价格水平、差价 率、利润率应当保持在合理幅度”.).

20 Graph from the "Ash Centre for Democratic Governance and Innovation”, Harvard University. 
and cultural forces compels individuals "to construct their own biographies without resorting to the socially integrating institutions of the first modernity", such as organized religion, workers unions, and organized science. In the second modernity, therefore, "personal religion" arises as yet another consumer commodity. In the same way as the consumption of consumer goods serves to fulfil one or other desire that is very often sold to the consumer, in the "individual religion" that incarnates the "individual choice" of the consumer, "self-realization and the search for sensation are the basic elements" (Bauman 1997,182). An important consequence of the creation of "individual religion" is that religion has lost its once universal character. That is to say, religion in a consumerist society brings together lonely "losers", i.e., those "who have been left behind in the struggle for the entrance tickets to the consumer's party. [...] the consumers who are not able to use the treasures that are shown seducingly within their reach" (ibid.). These lonely "losers" do, however, not shed their loneliness. On the contrary, the very fact that the new religious (or ideological) group of their choice has as little impact on decision making as they themselves, as individuals, have, results in their alignment with likeminded individuals that only reinforces their conviction that they stand alone. ${ }^{21}$ Adorno $(1998,118)$ in this respect stated that the hope of redemption is doomed to be frustrated, since the promise of a compensatory self-esteem "by proxy" is proffered by the self-same collective that makes admission conditional on the suspension or surrender of individuality. "Individual religion" is thus intricately connected to feelings of socio-economic and political impotence. In her study of the rise of qigong in China since the 1990s, Nancy N. Chen (2003, 199) stated the following:

At the onset of the 21st century, the Chinese state bureaucracy faces the recurrent issue of how to retain social order with ongoing market reform. Despite robust exports and access to new goods and job opportunities, the domestic economy has produced not only nouveau-riches but also vastly poorer individuals without a familiar net of state welfare or services available. In the midst of market expansion, alternative healing practices gave meaning to those who were being displaced in the new economic order and who came to embody social disorder. Followers were drawn

21 Bauman $(2005,47)$ phrased this as follows: "[O]nce the task of coping with human existential unsafety has been privatized and left to individual resources, individually experienced fears can only be 'head-counted', but not shred or melted into a common cause and the new quality of joint action. The privatization of fears has a self-perpetuating capacity." Note that this explains why individual religion in the era of second modernity also lies at the base of contemporary religious (and ideological) fundamentalism: different from premodern religion that was centered on the weakness of human beings as a group, individual religion of the contemporary era addresses the weakness of a particular human individual in its comparison with the power of the "globals-by-choice". Also see Cavanaugh $(2004,50)$. 
to the messages of inclusion where anyone could participate, especially those who had lost jobs or health care benefits. Such a context created a broad-based interest in healing, setting the stage for entrepreneurial masters and the formation of new healing practices.

Distrust in the established political institutions may similarly also incite a feeling for the need for alternative leadership. That is to say, the loss of trust in the traditional political agora may bring about the "belief" in populist leaders as a viable alternative - those who claim to understand the lot of the worker and the middle-class man who is pushed out of the system and forced to join the ever growing mass of "locals-by-default", but who are actually the executors of the neoliberal system that has reduced these same workers and middle-class men to amorphous consumers of populist ideas. Indeed, the consumer syndrome that is part and parcel of the neoliberal order also applies to ideology itself, as even ideology has become merchandise, to be sold on the "political market". ${ }^{22}$

The combination of the felt need for alternative political institutions/leadership and the growth of individual religion may help to explain distrust in science that is fostered by institutions that were traditionally linked to the nation state. That is to say, another side-effect of the hyper-individualization of the neoliberal "society" may be the rise of conspiracy theories. Flynn Murphy $(2020,51)$ in this respect noted that:

Trump has made assertions that the coronavirus was manufactured in a Chinese lab, and this and other incorrect conspiracy theories are influential: the results of one survey, published in October, show that almost one-quarter of people in the United Kingdom and the United States think that the coronavirus was engineered in a Chinese lab. ${ }^{23}$

As is known, the Chinese popular media is also not free from unscientific conspiracy mongering on the origin of the COVID-19 virus, although, generally speaking, as Gregory Poland remarks in the issue of The Lancet quoted at the beginning of this article:

China does not have the kind of raucous anti-vaccine, anti-science movement that is trying to derail the fight against COVID-19 in the USA. (Burki 2020)

22 See in this respect also the shrinking adherence to traditional political parties in many Western countries, the rise of one-issue political parties, or the rise of political parties who focus on locality-the geographical space to which the "locals-by-default" and their families are most closely connected.

23 To which, in the meantime, a whole series of more recent unscientific reportage can be added. 


\section{Conclusion}

A first conclusion that becomes apparent from the above is that in times of crisis, trust in the government is the key. This was, among other things, revealed in an opinion poll done in the Republic of Korea, about which Robert J. Fouser (2020) stated in The Straits Times:

In countries where citizens trust the government, people willingly cooperate. In countries where trust in the government is low, resistance builds and the shutdowns become politicised.

The diminished role of national governments that characterizes the neoliberal order appears to have brought the local level of governance back to prominence. Therefore, that

most western countries have missed the boat by not using the golden window period at the early days of the spread of the epidemic that the East Asian countries used to halt the COVID-19 epidemic, [...] necessitates them to strengthen early responses and community-centered public health systems, which are in place in some of the East Asian countries. (Shookoohi, Ossoli and Stranges 2020,1) (emphasis in original).

Looking at the broader socio-political implications the current COVID-19 crisis risks having, the necessity of reviving the political agora-local, national, and supranational-becomes prominent. The suggestions Soonhee Kim $(2010,808)$ made for Japan and for the Republic of Korea are also applicable to the Western world:

In order to build government leadership for enhancing public trust in government in democratic societies, government leaders can 1) encourage stakeholders to be creative and innovative in the development of new ideas and tools for enhancing economic development, transparency, and citizen participation; 2) promote and communicate vision and goals for enhancing public trust in government with internal stakeholders as well as external stakeholders; and 3) monitor government performance on economic development, transparency, and citizen participation. (author's emphasis)

I contend that, in times of increased Chinese-Western tension and in which, as alluded to in the "some first considerations" section of this article, the West appears to be increasingly doubting its own fundamental democratic principles, a 
revaluation of the political agora on all levels of governance is crucial to revive Western trust in its own values. In the same way as, in the developmental process of the first modernity, political consultation paved the way for enhanced individual freedoms and secured citizens in their individual discoveries of the world, a renewed focus on political consultation to rebalance the social and political excesses of neoliberalism-phenomena that undermine the very existence of liberal democracies - may be an important part of the road to safeguard our very existence as free citizens in a free world.

\section{References}

Adorno, Theodor Ludwig Wiesengrund. 1991. The Culture Industry: Selected Essays on Mass Culture by Theodor W. Adorno. Translated by Wes Blomster, edited by J. M. Bernstein. London: Routledge.

-1998. Critical Models: Interventions and Catchwords. Translated by Henry W. Pickford. New York: Columbia University Press.

Arendt, Hannah. [1951] 1958. The Origins of Totalitarianism. London: George Allen \& Unwin Ltd.

AsiaNerws.it. 2005. "Only Those with Money Can Afford Health Care in China." AsiaNerws.it, April 10. 2005. Accessed March 22, 2021. http://www.asianews.it/news-en/Only-those-with-money-can-afford-health-care-in-China-4263.html.

Bauman, Zygmunt. 1997. Postmodernity and Its Discontents. Cambridge: Polity Press.

— . [1999] 2006. In Search of Politics. Cambridge: Polity Press.

. [2005] 2020. Liquid Life. Cambridge: Polity.

Bell, Daniel A. 2006. Beyond Liberal Democracy. Political Thinking for an East Asian Context. Princeton, Oxford: Princeton University Press.

Biscop, Sven. 2020. “Can Corona Cure Our Superiority Complex?” Egmont Paper November 9, 2020.

Bourdieu, Pierre. 1997. "La précarité est aujourd'hui partout." Contre-feux, Grenoble: Ed. Liber Raisons d'agir.

Burki, Talha. 2020. "China's Successful Control of COVID-19." The Lancet Infectious Diseases 20 (11): 1240-41. Accessed March 1, 2021. https://www. thelancet.com/journals/laninf/article/PIIS1473-3099(20)30800-8/fulltext.

Castells, Manuel. 2009. The Information Age: Economy, Society, and Culture. Vol. II: The Power of Identity. Chichester: Wiley-Blackwell.

2010. The Information Age: Economy, Society, and Culture. Vol. III: End of Millennium. Chichester: Wiley-Blackwell. 
Cavanaugh, William T. 2004. "Sins of Omission: What 'Religion and Violence' Arguments Ignore." The Hedgehog Review. Critical Reflections on Contemporary Culture 6 (1): $34-50$.

Chen, Nancy N. 2003. "Healing Sects and Anti-Cult Campaigns." In Religion in China Today, edited by Daniel L. Overmyer, 199-214. The China Quarterly Special Issues New Series, no. 3. Cambridge: Cambridge University Press.

Cheng Anne. 1997. Histoire de la pensée chinoise. Paris: Seuil.

"China Health Care Forum Summary Report (2005-2015)." Accessed March 28, 2021. https://en.ceibs.edu/sites/default/files/industry-forums/summary-report/Summary_Healthcare\%20Forum\%202015_E.pdf.

Cohen Myron L. 1976. House United, House Divided: The Chinese Family in Taiwan. New York: Columbia University Press.

Ding, Yining. 2021. "China Continues to Lead World in Number of Billionaires." Shine, March 2, 2021. Accessed March 27, 2021. https://www.shine.cn/biz/ economy/2103025324/.

El Amine, Loubna. 2015. Classical Confucian Political Thought. A New Interpretation. Princeton, Oxford: Princeton University Press.

European Commission. 2020. "The Corruption Perception Index 2019: The EU is the Best Performer in the World." European Commission, January 27, 2020. Accessed 13 March, 2021. https://ec.europa.eu/regional_policy/en/newsroom/news/2020/01/27-01-2020-the-corruption-perception-index-2019the-eu-is-the-best-performer-in-the-world.

Fei, Xiaotong. 1992. From the Soil. The Foundations of Chinese Society. Berkeley: University of California Press.

Fitoussi, Jean-Paul. 1997. "Europe: le commencement d'une aventure." Le Monde, August 29, 1997.

Fouser, Robert J. 2020. "Public Trust Key to Developing a Pandemic Response: Korea Herald Contributor." The Straits Times, September 1, 2020. Accessed March 5, 2021. https:/www.straitstimes.com/asia/public-trust-key-to-developing-a-pandemic-response-korea-herald-contributor.

Goldblatt, Howard. trans. 1993. Red Sorghum. New York: Penguin Books.

Hansen, Chad. 1985. "Individualism in Chinese Thought." In Individualism and Holism: Studies in Confucian and Taoist Values, edited by Donald J. Munro, 35-55. Ann Arbor: Center for Chinese Studies, The University of Michigan. Harrison, Henrietta. 2001. China. Inventing the Nation. London: Arnold.

Kaufman, Joan. 2010. "Policy Case Study: Public Health." In Politics in China. An Introduction, edited by William A. Joseph, 288-97. Oxford: Oxford University Press.

Kim, Soonhee. 2010. "Public Trust in Government in Japan and South Korea: Does the Rise of Critical Citizens Matter." Public Administration Review 70 (5): 801-10. 
Knoblock, John. 1990. Xunzi. A Translation and Study of the Complete Works. 3 vols. Stanford: Stanford University Press.

Mak, Geert. 2019. Grote verwachtingen. In Europe 1999-2019. Amsterdam: Atlas Contact.

Mo, Yan 莫言. 2021. Hong gaoliang jiazu 红高粱家族. Accessed March 13, 2021. http://www.dushu369.com/zhongguomingzhu/myzpj/hgljz/.

Murphy, Flynn. 2020. "Inside China's Response to Covid. Researchers and Officials Reveal How the Pandemic has Shifted the Country's Scientific Landscape and Global Reputation." Nature 588: 49-51.

Peerenboom, Randall. 2007. China Modernizes. Threat to the West or Model for the Rest? Oxford: Oxford University Press.

Perry, Elizabeth J. 2001. Challenging the Mandate of Heaven: Social Protest and State Power in China. Armonk: M.E. Sharpe.

Redding Gordon S. 1995. The Spirit of Chinese Capitalism. Berlin, New York: de Gruyter.

Schmidt-Glintzer, Helwig. 2009. Chinas Angst vor der Freiheit. Der lange Weg in die Moderne. München: Verlag Beck.

Shookoohi, Mostafa, Mehdi Osooli, and Saverio Stranges. 2020. "Covid-19 Pandemic: What Can the West Learn From the East?" International Journal of Health Policy and Management X (X): 1-3.

Speck, Simon. 2013. "Religion, Individualism and Consumerism: Constructions of Religiosity in 'Liquid' and 'Reflexive' Modernity." In Religion in Consumer Society. Brands, Consumers and Markets, edited by François Gauthier, and Tuomas Martikainen, 27-42. Surrey: Ashgate.

Standing Committee of the National People's Congress. 2019a. "Law of the People's Republic of China on the Promotion of Basic Medical and Health Care.” Accessed May 29, 2021. http://www.lawinfochina.com/display. aspx?id=31894\&lib=law.

Standing Committee of the National People's Congress. 2019b. "Vaccine Administration Law of the People's Republic of China." Accessed May 29, 2021. http://www.gov.cn/xinwen/2019-06/30/content_5404540.htm.

Stover, Leon E. 1974. The Cultural Ecology of Chinese Civilization. Peasants and Elites in the Last of the Agrarian States. New York: The New American Library.

The Economist. 2020. "Why Worry? China, Public Satisfaction with Government." The Economist, October 20, 2020.

The Economist Intelligence Unit. 2020. "Democracy Index 2020: In Sickness and in Health?" Accessed March 22, 20121. https://www.eiu.com/n/campaigns/ democracy-index-2020/.

Tucker, Robert C. 1978. The Marx-Engels Readers. London, New York: W. W. Norton. 
Verhaeghe, Paul. 2020. Houd Afstand. Raak me aan. Amsterdam: De Bezige Bij. Wang, Tim, William Morris, and Richard Brubaker. 2016. Sustainability Insights. China's Elderly. Accessed March, 22, 2021. https://www.coresponsibility.com/ wp-content/uploads/2016/06/Elderly-in-China.pdf.

WHO. n.d. "Severe Acute Respiratory Syndrome (SARS)." Accessed March 13, 2021. https://www.who.int/health-topics/severe-acute-respiratory-syndrome\#tab=tab_1. Wilson, Richard W., and Amy W. Pusey. 1982. "Achievement Motivation and Small Business Relationship Patterns in Chinese Society." In Social Interaction in Chinese Society, edited by Sidney L. Greenblatt, Richard W. Wilson, and Amy A. Wilson, 195-208. New York: Praeger.

Wolf, Eric. R. 1966. Peasants. Englewood Cliffs: Prentice-Hall.

Xunzi «荀子», Bai jia zhu zi 百家諸子, 中國哲學書電子化計劃. Accessed March 13, 2021. https://ctext.org/xunzi/zh.

Yip, Winnie, and William C. Hsia. 2008. "The Chinese Health System at a Crossroads." Health Affairs 27 (2): 460-68.

\section{Appendix}

Ranking and figures of total number of infections and death toll of a selected number of European and Asian countries, and of the United States (total number of countries listed: 192).

9 December 2020, 09:26

\begin{tabular}{|l|c|c|c|}
\hline Country & Rank & Total infections & Total death toll \\
\hline United States & 1 & $15,171,676$ & 286,307 \\
\hline India & 2 & $9,735,850$ & 141,360 \\
\hline France & 5 & $2,363,197$ & 56,453 \\
\hline Italy & 6 & $1,757,394$ & 61,240 \\
\hline United Kingdom & 7 & $1,754,911$ & 62,130 \\
\hline Spain & 8 & $1,702,328$ & 46,646 \\
\hline Germany & 11 & $1,229,269$ & 20,002 \\
\hline Poland & 13 & $1,076,180$ & 20,592 \\
\hline Belgium & 19 & 594,572 & 17,507 \\
\hline Netherlands & 21 & 579,997 & 9,857 \\
\hline Czech Republic & 24 & 556,927 & 9,136 \\
\hline Sweden & 36 & 297,732 & 7,200 \\
\hline Japan & 47 & 167,367 & 2,334 \\
\hline
\end{tabular}




\begin{tabular}{|l|c|c|c|}
\hline Denmark & 68 & 95,332 & 901 \\
\hline China & 71 & 93,782 & 4,747 \\
\hline South Korea & 88 & 39,342 & 556 \\
\hline Taiwan & 159 & 718 & 7 \\
\hline
\end{tabular}

(Source: Johns Hopkins University: https://coronavirus.jhu.edu/maps.html)

1 March 2021, 13:24

\begin{tabular}{|l|c|c|c|}
\hline Country & Rank & Total infections & Total death toll \\
\hline United States & 1 & $28,606,177$ & 513,092 \\
\hline India & 2 & $11,112,241$ & 157,157 \\
\hline Brazil & 3 & $10,551,259$ & 254,942 \\
\hline Russia & 4 & $4,209,850$ & 85,025 \\
\hline United Kingdom & 5 & $4,188,827$ & 123,083 \\
\hline France & 6 & $3,815,639$ & 86,580 \\
\hline Spain & 7 & $3,188,553$ & 69,142 \\
\hline Italy & 8 & $2,925,265$ & 97,699 \\
\hline Germany & 10 & $2,452,346$ & 70,154 \\
\hline Poland & 14 & $1,711,772$ & 43,793 \\
\hline Czech Republic & 20 & $1,240,051$ & 20,469 \\
\hline Netherlands & 21 & $1,103,564$ & 15,688 \\
\hline Belgium & 27 & 771,511 & 22,077 \\
\hline Sweden & 29 & 657,309 & 12,826 \\
\hline Japan & 38 & 432,736 & 7,939 \\
\hline Denmark & 58 & 211,883 & 2,362 \\
\hline China & 84 & 100,979 & 4,836 \\
\hline South Korea & 85 & 90,031 & 1,605 \\
\hline Taiwan & 172 & 955 & 9 \\
\hline
\end{tabular}

(Source: Johns Hopkins University: https://coronavirus.jhu.edu/maps.html) 